\title{
An Empirical Study of the Effects of Demographic Factors on Economic Growth in Advanced and Developing Countries
}

Serhii Kozlovskyi

Sc.D., Professor, Vasyl' Stus Donetsk National University, Vinnytsia, Ukraine

e-mail: s.kozlovskyy@donnu.edu.ua

\section{Mykola Pasichnyi}

Sc.D., Associate Professor, Kyiv National University of Trade and Economics, Kyiv, Ukraine, e-mail: m.pasichnyi@knute.edu.ua

\section{Ruslan Lavrov (iD}

Sc.D., Professor, Chernihiv National University of Technology, Chernihiv, Ukraine, e-mail: lavrus2017@gmail.com

\section{Natalya Ivanyuta (iD)}

Sc.D., Associate Professor, Donetsk Law Institute of the Ministry of Internal Affairs of Ukraine, Mariupol, Ukraine, e-mail: natalaivanuta9@gmail.com

Anton Nepytaliuk

Ph.D. student, Vasyl' Stus Donetsk National University, Vinnytsia, Ukraine e-mail: anton.nepytaliuk@gmail.com

\begin{abstract}
In this article, an updated approach to investigate the effects of demographic factors on economic growth is proposed. The initial hypothesis was that these factors significantly affected production proportions, determining development vectors. The predictable shifts in production dynamics are considered for the institutional framework. The article investigates the statistically significant relationships between the demographic variables and economic growth for the sample of the OECD countries (excluding Columbia) and Armenia, Belarus, Bulgaria, Croatia, Georgia, Kazakhstan, Romania, the Russian Federation, and Ukraine, from 1990 to 2017; unbalanced
\end{abstract}


panel data was used. The investigation aimed to highlight the intrinsic interconnection between the changes in demographic variables (e.g., the working-age population growth rate and the average life expectancy growth rate) and economic growth. Our investigation focused on the issue of whether demographic influence on economics was the same for advanced and developing countries in the sample. Over the period, a significant increase in life expectancy adversely affected the real GDP per capita growth rate. However, the empirical study pointed out that life expectancy was strongly linked to nominal GDP per capita. In advanced countries, the demographic indicator was considerably higher than in emerging markets. We found that the rise in the working-age stratum of the nation's population radically reduced the output dynamics as well, but that interconnection was not robust. The institutional framework should be taken into account in order to achieve a favorable performance of public governance in the long-run. The main demographic variables should be properly forecasted and calibrated for potential endogenous economic triggers. Both public and private investments are important when considering the economic growth rates that are achieved. We propose a balanced approach to macroeconomic policy regarding both demographic and institutional determinants.

Keywords: population, human capital, demographic sustainability, institutional framework, economic growth

JEL: E22, I30, J10, J18, J24, O10

\section{Introduction}

There are several indisputable reasons to investigate the population's impact on economic development - with inherent social and demographic characteristics - regarding growth theories. Firstly, the actual level of public welfare is sensed and described only through human consciousness. Secondly, a person with his own needs and desires creates the initial tasks for public production and directly participates in that process. So, the nation's population simultaneously plays the roles of the aggregated producer and consumer of goods and services. The individual's economic behavior causes and, at the same time, is caused by higher interests, which are represented by social groups (e.g., nations, economic classes, strata, etc.). General changes in the population's number, density, and age structure unquestionably affect public production. After centuries of relatively slow and uneven growth, the world population reached 1 billion nearly two hundred years ago. Before the start of the first so-called demographic transition, there were countless births and deaths, human life expectancy was short, and the population was generally young.

Due to the transition, mortality and then fertility seriously declined. The population growth rates accelerated and then - unequally for advanced and the third-world countries - they fell again, matching low fertility, extended life spans, and a rather old population. During the second half of the $20^{\text {th }}$ century, the total population growth accelerated at an unprecedented rate. The aforementioned global demographic chang- 
es brought decisive changes, reshaped both the economic and demographic life-cycles of the individuals, and restructured communities. As a result, the current world population exceeds 7.7 billion, and it is expected to increase at a constant rate for at least the next several decades.

This has raised lots of economic, social, and ecological questions (e.g., the societal costs of the elderly, the redistribution of responsibility between the generations, the lack of food provision, global pollution, etc.). The population's characteristics were considered to be the main economic growth determinants. So, their complex impact on the development processes is everlasting and should be evaluated properly. The issues related to the key factors of economic growth have been at the heart of economic science since its origin. Nearly five centuries of profound investigations have produced a plethora of sustainable development theories, but the uncertainty remains.

In the vast majority of those theories, the main demographic variables are regarded as endogenous determinants. On the one hand, everyone possesses a unique combination of productive capacities that should be viewed as a part of human capital. On the other hand, the population is jointly characterized by an essential economic potential, which eventually results in output. Thus, modern demography and economics merged to propose some theoretical and practical statements on production improvement. Even though demographic issues are traditionally associated with fertility and mortality rates, in this paper, we consider demographic variables in a broad sense, including aggregated knowledge, the purposeful skills of the workforce, the potential of education and public health, etc. Some of the above characteristics overlap, so it is crucial to identify and separate their influence on the growth processes.

The ongoing shifts in the demographic structure have enabled national economies to convert most of the benefits from factor accumulation and technological changes into income per capita growth. Both labor productivity and development processes were generally enhanced via three channels. Firstly, the downtrend in population growth has limited stock dilution and simultaneously increased the number of resources per capita. Secondly, the reduced fertility sanctioned the reallocation of resources from quantity toward the quality of children, intensifying the human capital formation and total labor productivity. Finally, the reduction in fertility rates changed the age distribution of the population. So, if the fraction of the labor force in the population temporarily increased, productivity per capita could be raised mechanically.

The overall influence of the population change on economic growth and performance is ambiguous. There are alternative possibilities that population growth is supportive, restrictive, or neutral to economic development. The changes in population number and density are commonly interconnected with some shifts in the community's age structure. The latter could be described as the population's distribution across different age groups. Human economic behavior varies depending on the different stages of the individual's life. Thus, nations with an enormously high proportion of children should devote most of their resources to childcare programs. That fact 
depresses the pace of economic growth in the short-run but could be associated with intensified human capital acceleration in the long-run.

By contrast, if most of a nation's population belongs to the working-age stratum, the extended productivity of that group can produce the so-called "demographic dividend." If the nation's population consists of the elderly, the effects can be different. On the one hand, the result can be similar to the case of a very young population, when a large share of resources is consumed by a relatively less productive population segment, inhibiting economic growth. On the other hand, the elderly, for many reasons (primarily, effective public health care), can maintain working capacity and demonstrate significant labor productivity, especially in the tertiary and quaternary sectors of the economy.

A demographic dividend should be emphasized that considers both productivity and consumption. It should be specifically mentioned that a demographic dividend in the modern scientific discourse exists in two different forms. The "first" demographic dividend is caused by an increase in the share of countries' populations that are concentrated in the working ages. Economically active individuals form the main factor responsible for development.

The "second" dividend is much more difficult to explain. A rapid growth in the elderly stratum presumably strains the public pension and health care systems. Over recent decades, this has led to pessimistic forecasts concerning future economic performance. Nevertheless, an aging population can be a source of a second demographic dividend rather than an economic decline. While the economically productive population stratum is declining, a major challenge for aging and aged societies is to provide a favorable framework for specific old-age consumption and to achieve a desirable level of public welfare. The legislative framework is indirectly connected with the above problem, but the main task for smart public governance is to provide a favorable configuration of the financial system.

Demographic dividends do not occur automatically; their scale is largely dependent on the quality of public institutions. The weaknesses of possible pension programs (e.g., an unsustainable increase in public pension benefits or critical tax evasion) could offset many of the potential demographic dividends. For example, if most of the increases in labor supply are concentrated in the informal sector, which does not contribute to social security finances, it can cause imbalances and a decline in public welfare. The most significant factors for sustainable development demographic variables are represented by both the qualitative and the quantitative parameters of the working-age population. But the age dependency ratio is not the only demographic characteristic that matters. Fertility and mortality fluctuations affect the average life expectancy and determine the age distribution between the population strata. Even though increased life expectancy is interconnected with life quality, it usually reshapes public finances and potentially induces a tax burden. The quality of human capital depends on aggregate public and private productive expenses. Thus, the model of sustainable economic growth should combine the parameters related to human and physical capital creation. 
Development trends in advanced, emerging-market, and third-world economies are incomparable. Moreover, in the above groups, a sub-group of commodity economies should be specified regarding a wide range of factors. Even though all economies are dependent on the same endogenous development triggers, the scale and the proportion of those growth determinants significantly vary. In this study, we primarily examine advanced (OECD member-states) as well as some emerging, post-Soviet (Armenia, Belarus, Bulgaria, Croatia, Georgia, Kazakhstan, Romania, the Russian Federation, and Ukraine) economies over the periods of institutional transformation and sustainable growth. We reveal the overall dual impact on economic development of an expansion in the working-age population stratum and the increased life expectancy.

\section{Literature review}

Rethinking Romer's (1990) conceptual model of endogenous technical change, Malmberg (1994) proposed combining it with human capital and the life-cycle of savings theories. He also argued that the population's age structure was crucial. Due to the profound analysis of the changes in financial behavior and human capital accumulation over the life-cycle, a theory of the age pattern of economic growth effects was highlighted. Bloom, Canning, and Sevilla (2001; 2003) examined the impact of population change on economic growth, regarding the alternative positions that population growth restricted, promoted, or appeared to be neutral to economic growth trends. They identified not only the impact of the size and growth rate of the population on economic performance but the effects of the age structure. The agents' behavior was described as being highly dependent on the structure. They concluded that, on the concept of a demographic dividend, the effect of an optimal working-age population combined with health care, and educational, financial, and human capital policies could initiate decent cycles of wealth creation.

Due to the enormous range of empirical cases, the evidence on the relevance of the shifts in the age structure for economic growth was highlighted. The concept of a demographic dividend was further developed by Bloom et al. (2007; 2009). The age structure was considered to be a crucial determinant of economic growth and the main forecast objective. Boucekkine, de la Croix, and Licandro (2002) identified and empirically proved that endogenous economic growth was caused by the accumulation of generation-specific human capital. While preferable shifts in the survival probabilities resulted in an extended schooling period and later retirement, their effect on economic growth was ambiguous. Demographic variables had significant medium-term economic effects, but the numerical interdependencies in the long-run did not appear to be robust. Kozlovskyi et al. (2019) pointed out the essence of economic security management for an emerging economy under conditions of globalization. The interrelation between security issues and life quality dynamics was generally revealed. 
Lee $(2001 ; 2003)$ summarized the main evidence of the demographic transition and the related issues over the last three centuries. Considering the retrospective data on the multiple interrelations between population shifts and fiscal policy performance, he sketched the possible demographic changes and their economic consequences for advanced and emerging markets. Taking human capital theory into account, numerous papers are dedicated to the essential social and demographic determinants of both economic and population growth. Gador (2012) revealed the empirical validity of the main demographic theories and their relevance for a sound understanding of the transition from the stagnation phase to sustainable growth. A significant increase in the demand for human capital in the development process was suggested as being the main trigger for fertility reduction as well as the transition to the present growth rates.

Acemoglu and Johnson (2007) and Hansen and Lønstrup (2015) proved that an increase in life expectancy over the second half of the $20^{\text {th }}$ century simultaneously reduced the real GDP per capita growth rate and fostered population growth. That dual conclusion was based on the fact that, due to medical breakthroughs, many advanced countries have experienced high growth rates in life expectancy and population size, and low growth rates in per capita GDP. Based on empirical evidence from Western economies during the past century, Fernihough (2017) revealed the importance of the demographic transition as a support mechanism for the growth of human capital. The impact of education on fertility rates and human capital accumulation was also investigated.

Lucas Jr. (2015) examined the aggregate innovative potential of the nation as a result of knowledge creation based on consistent schooling and skills improvement. Meanwhile, the actual role of knowledge management was dependent on the initial level of the country's economic development and the quality of the institutional framework. Barro and Lee (2013) investigated how output was related to the stock of human capital, which was determined by the total years of schooling and by the composition of the workers' educational attainment. Education had a significantly positive effect on the output dynamics, optimizing the endogenous interrelations between the main components of economic growth.

Significant conclusions were made regarding human capital production. Using panel data, Pelinescu (2015) proved the value of a good education and a flexible training system for sustainable economic growth. Knowledge diffusion in manufacturing goods and services, creative industries, and concrete efforts to establish a research-intensive economy were identified as the main triggers responsible for long-term development. Hanushek (2015) examined the possibilities for a tertiary education-based improvement in public production. No statistically significant interdependencies between the indicators mentioned were revealed. Nevertheless, reasonable effects of education were observed. Ahsan and Haque (2017) refuted the hypothesis that the years of schooling were unrelated to economic growth. According to their empirical study, a decisive influence of education could be discerned after a particular economy exceeds a threshold development level.

Using a growth model with integrated variables from the supply and demand side, Teixeira and Queirós (2016) assessed the direct and indirect effects of human capital 
on output growth, including the interaction of human capital with the country's industrial specialization. Both human capital dynamics and the country's productive specialization were identified as the main economic growth determinants.

Economic development was strongly influenced by the composite effect of human capital applications and structural change in high knowledge-intensive industries. Meanwhile, the sign of the observed effect depended on the type of economic model and the analyzed period. Over a long-time period (1960-2011), the cumulative impact of the interaction between human capital and structural change appeared to be positive for OECD countries. Nagarajan, Teixeira, and Silva (2016) reviewed the literature regarding the aging population and its integral impact on economic growth, and they discovered the main mechanisms by which aging affected development.

Applying different mathematical methods, Uddin, Alam, and Gow (2016) investigated population saving behavior regarding age structure, dependency ratio, savings rate, and real GDP. The negative effect of population aging on advanced economies was statistically proved. Meanwhile, McGrath (2016) concluded that the indicators of GDP, capital stock, and human capital were co-integrated. While the causalities from GDP to capital stock and from capital stock to human capital were bidirectional, the causality from GDP to human capital appeared to be unidirectional, but not vice versa. As a result, the initial hypothesis that economic growth was caused by human capital has been generally refuted.

Focusing on the differences in the mortality rate for comparative development, Cervellati and Sunde (2015) proposed a unified growth theory - covering both demographic and economic issues - and investigated the demographic transition's mechanics. The results explained an essential part of the differences in economic development (e.g., the timing of the takeoff) across countries under study and the worldwide density distribution of the main demographic variables.

Acemoglu and Restrepo (2017) disputed the negative effects of an aging population on economic development. The main theoretical statements on the possible negative effects of an aging population on economic growth were empirically investigated. Both the lower labor force participation and productivity decreasing of the older employees were considered. The hypothesis that aging had a negative impact on the savings-to-investment ratio and led to so-called secular stagnation was not supported. It should be mentioned that the authors applied a rather unusual methodology: all the population over 50 was identified as "aged," irrespective of the person's production activity and economic behavior. Cooley, Henriksen, and Nusbaum (2019) identified persistent deceleration in economic growth rates of the four largest advanced economies in Europe caused by a shift in the age-cohort distribution. Defining the impact of complex demographic factors on economic development, they revealed some interdependencies between the total factor productivity, capital accumulation, labor supply, and population growth. They proved that the effects of an aging population on economic growth distorted individual factor-supply choices regarding the pension systems. 
Ahmad and Khan (2019) empirically investigated whether the demographic transition and the dynamics of human capital mattered for economic growth for a representative sample of the developing world. The positive lagged contribution of the economically active population and the labor force participation rate in economic growth were identified. Kozlovskyi et al. (2018) investigated the Ukrainian agrarian sector's regional peculiarities in the context of sustainable development. As an essential precondition for economic growth, they highlighted a strong interconnection between sound management in the above sphere and the human capital quality.

Regarding the shift in advanced countries from industrial to knowledge economies, Faggian, Partridge, and Malecki (2017) investigated the underlying causes of endogenous economic development. The main prerequisites for growth were defined as intensified creativity, an entrepreneurship environment, and expanded human capital; those factors were linked to the demographic parameters of the nation. While the interrelation between human capital (measured by educational attainment) and business environment (characterized by the intensity of small and medium-sized firms) appeared to be statistically interconnected with subsequent growth, other factors (e.g., the share of creative class workers, the share of advanced technology industries, etc.) were described as insignificant. Meanwhile, Cuaresma et al. (2018) assessed the potential contribution of future educational attainment to economic growth and income convergence. They suggested that income convergence dynamics and human capital acted as important drivers for real income growth.

\section{The aims}

This paper investigates the interrelation between selected demographic variables and the main economic variables regarding OECD and some developing countries. The possible and predicted demographic dividends and the general character of the impact of the demographic transition on economic development processes are examined. We try to find effective public management measures regarding the highlighted demographic trends.

\section{Methods and data}

Sustainable economic development is dependent on a dynamic interrelation between economic and demographic factors. Their overall effect is described by a production function (1):

$$
Y=f\left(x_{1}, x_{2}, \ldots, x_{n}\right)
$$


where $Y$ - the national production capacity or annual economic growth; $x_{1}, x_{2}, \ldots, x_{n}$ - the most essential economic and demographic factors.

Those factors are deeply interconnected with the category of human capital. Meanwhile, all the significant elements of the aforementioned category are mostly inseparable and overlap. In our investigation, public production is defined by the Cobb-Douglas function (2).

$$
Y_{i j}=A_{i j} * L_{i j}^{\alpha} * K_{i j}^{\beta},
$$

where

$Y_{i j}$ - real GDP of country $j$ in the year $i$;

$A_{i j}$ - the total factor productivity coefficient of country $j$ in year $i$;

$L_{i j}$ - the labor input of country $j$ in year $i$;

$K_{i j}$ - the capital input of country $j$ in year $i$;

$\alpha, \beta$ - the output elasticities of labor and capital, respectively, while $\alpha+\beta=1$.

In present conditions, all production factors should be regarded as imperfect complements. Public welfare could be described by the real annual GDP per capita growth rate. The latter is dependent on the main productive factors, namely, physical and human capital. If the real GDP per capita growth rate is decomposed into several conditionally independent variables, multiplicative function (2) can be transformed into an additive one (3):

$$
\operatorname{growt}_{\mathrm{ij}}=\gamma_{0}+\gamma_{1} \text { demogr }_{\mathrm{ij}}+\gamma_{2} \text { hum_cap }_{i j}+\gamma_{3} \operatorname{contr}_{i j}+\varepsilon \text {, }
$$

where

growth $_{i j}$ - the real GDP per capita growth rate of country $j$ in year $i$;

demogr $_{i j}$ - the demographic variables of country $j$ in year $i$;

hum_cap $p_{i j}$ - the other human capital variables (indirectly related to the demographic ones) of country $j$ in year $i$;

contr $_{i j}$ - the economic controls (related to the physical capital) of country $j$ in year $i$.

The OLS method was applied to evaluate the overall impact of demographic and other selected determinants on economic development.

Demographic variables are traditionally associated with fertility and mortality rates. Broadly, the population's dynamics depend not only on natural factors but on mechanical ones as well (e.g., migration). We strongly believe that the overall demographic impact on economic growth is represented by the permanent changes in the working-age population stratum and expected life span dynamics. So, the demographic variables of our study consist of the working-age population growth rate (WAPop $\left.p_{g r}\right)$ and the average life expectancy growth rate $\left(\right.$ LifeExp $\left.p_{g r}\right)$. The other human-capital-related essential economic growth determinant is represented by the composite public and private expenses on research and development activities $\left(R D_{\% G D P}\right)$, regarded as a percentage of GDP. 
In addition, we impose two economic controls: public expenditures (PubExp\%GDP) and total investment $\left(\operatorname{TIn} v_{\% G D P}\right)$ as percentages of GDP. Public spending characterizes the scale of GDP redistribution and the government's role in welfare creation processes. That variable aggregates both the productive expenses (related to human capital formation) and the other expenditures with an ambiguous impact on economic growth (regarded as unproductive). Aggregating public and private financial activity simultaneously, the total investment indicator is related primarily to the physical capital production of the Cobb-Douglas function.

We used a panel data analysis over the period 1990-2017. The sample included the economies of the OECD countries (excluding Columbia) and the economies of Armenia, Belarus, Bulgaria, Croatia, Georgia, Kazakhstan, Romania, the Russian Federation, and Ukraine. Due to a critical lack of information on several emerging markets in the early 1990s, the panel data was unbalanced. Because the vast majority of the studied emerging economies successfully conducted institutional and structural reforms before joining the EU (and its principal formation ended around 2004-2005), we examined two periods: 1990-2004 and 2005-2017.

The main sources of our empirical data were the databases of the World Bank and the IMF. Some essential data were drawn from the databases of the OECD and the European Commission. Summary statistics data for the sample regarding the three periods are presented in Table 1.

Table 1. Summary statistics

\begin{tabular}{|c|c|c|c|c|c|c|}
\hline Variables & Period & Observations & Mean & Standard deviation & Max & Min \\
\hline \multirow{3}{*}{$G D P p c_{g r}$} & $1990-2017$ & 1032 & 2.35 & 3.64 & 23.99 & -14.56 \\
\hline & 1990-2004 & 465 & 2.89 & 3.25 & 15.31 & -12.16 \\
\hline & $2005-2017$ & 567 & 1.90 & 3.88 & 23.99 & -14.56 \\
\hline \multirow{3}{*}{ LifeExp $_{g r}$} & $1990-2017$ & 1032 & 0.31 & 0.38 & 2.34 & -1.59 \\
\hline & 1990-2004 & 465 & 0.31 & 0.37 & 2.34 & -1.59 \\
\hline & $2005-2017$ & 567 & 0.30 & 0.38 & 2.10 & -1.03 \\
\hline \multirow{3}{*}{ WAPop $_{g r}$} & $1990-2017$ & 1032 & 0.34 & 0.94 & 4.93 & -4.08 \\
\hline & 1990-2004 & 465 & 0.48 & 0.85 & 4.93 & -4.08 \\
\hline & $2005-2017$ & 567 & 0.23 & 1.00 & 3.03 & -2.48 \\
\hline \multirow{3}{*}{$R \& D_{\% G D P}$} & $1990-2017$ & 1032 & 1.52 & 0.94 & 4.58 & 0.08 \\
\hline & 1990-2004 & 465 & 1.41 & 0.81 & 4.19 & 0.19 \\
\hline & $2005-2017$ & 567 & 1.60 & 1.03 & 4.58 & 0.08 \\
\hline \multirow{3}{*}{ PubExp ${ }_{\% G D P}$} & $1990-2017$ & 1032 & 41.39 & 9.47 & 68.03 & 13.79 \\
\hline & 1990-2004 & 465 & 42.22 & 9.89 & 68.03 & 13.79 \\
\hline & $2005-2017$ & 567 & 40.71 & 9.06 & 65.05 & 18.63 \\
\hline \multirow{3}{*}{$T I n v_{\% G D P}$} & $1990-2017$ & 1032 & 23.70 & 4.59 & 43.81 & 10.22 \\
\hline & 1990-2004 & 465 & 23.70 & 4.01 & 39.02 & 11.89 \\
\hline & $2005-2017$ & 567 & 23.71 & 5.02 & 43.81 & 10.22 \\
\hline
\end{tabular}

Source: authors' own calculation based on The International Monetary Fund Database (2019), The World Bank Open Data (2019), The European Commission Database (2019), and The OECD Data (2019). 
Over the period 1990-2017, all the analyzed indicators varied significantly. While the volatility - characterized by the standard deviation - of the public expenditures-to-GDP ratio reduced slightly, the volatility of the other examined indexes increased. Meanwhile, the aforementioned ratio was characterized by the highest standard deviation, which equaled $9.47 \%$. This was due to the remarkable differences in the sampled countries' institutional framework, fiscal policies, and economic models.

\section{Results}

Sustainable growth is described as the ultimate and primary objective of an economic policy in the long-run. Different demographic variables are traditionally integrated into development programs and strategies as their most significant indices. Yet, the actual role of the population's characteristics as the growth triggers remains unknown. Set by the authorities due to electoral obligations and commitments regarding the mutual interconnection between political and business cycles, some declarative goals in the distinct fields (e.g., demographics, public finances, etc.) can contradict each other and deteriorate the analyzed system's overall effect. Given the above, a complex numerical investigation of the contribution of both demographic and non-demographic factors to economic growth was carried out.

Sanchez-Romero, Lee, and Prskawetz (2018) pointed out that differences in life expectancy are observed not only between different countries but between high and low socioeconomic groups as well. That hypothesis is extremely important when societies with significant inequalities are analyzed. However, in our investigation, both life expectancy and economic development indicators are regarded as the universal characteristics of a particular nation's population. Figure 1 represents the interrelation between the mean GDP per capita (expressed in current US \$) and total life expectancy at birth (expressed in years) in the sample over the period 1990-2017. The observed interdependency appeared to be statistically significant and quite robust $\left(R^{2}=0.58\right)$. Regarding the empirical data on the mean GDP per capita, the sample was divided into three sub-samples. The $1^{\text {st }}$ sub-sample included countries with a mean GDP per capita lower than US $\$ 12,500.00$; the $2^{\text {nd }}$ sub-sample - countries with a mean GDP per capita from US $\$ 12,500.01$ to US $\$ 37,500.00$; the $3^{\text {rd }}$ sub-sample - countries with a mean GDP per capita higher than US $\$ 37,500.01$.

The vast majority of post-Soviet countries were included in the $1^{\text {st }}$ sub-sample due to their rather unfavorable endogenous social and economic conditions in the early 1990s. The $1^{\text {st }}$ sub-sample also included Chile, Mexico, and Turkey. Meanwhile, over the entire period, Slovenia appeared to be the only post-Soviet country with a sufficiently high average GDP per capita that was equal to US $\$ 16,221.94$. Considering the entire sample, the countries of the $1^{\text {st }}$ sub-sample were characterized by the lowest average life expectancy; the indicator varied from 67.47 years in Kazakhstan to 75.64 years in the Czech Republic. The average life expectancy in Slove- 
nia (77.03 years) was slightly lower than in Chile (77.08 years). In the $2^{\text {nd }}$ and the $3^{\text {rd }}$ sub-samples, the interconnection was generally the same, but its statistical density appeared to be weaker. The highest average life expectancy at birth was observed in Japan (81.60 years). Australia, Italy, and Spain (from the $2^{\text {nd }}$ sub-sample) as well as Iceland, Sweden, and Switzerland (from the $3^{\text {rd }}$ sub-sample) formed a group of countries with an average life expectancy that exceeded 80.00 years. Kazakhstan, the Russian Federation, and Ukraine formed a group of countries with the lowest average life expectancy, which did not exceed 70.00 years. The group was also characterized by the lowest average GDP per capita.

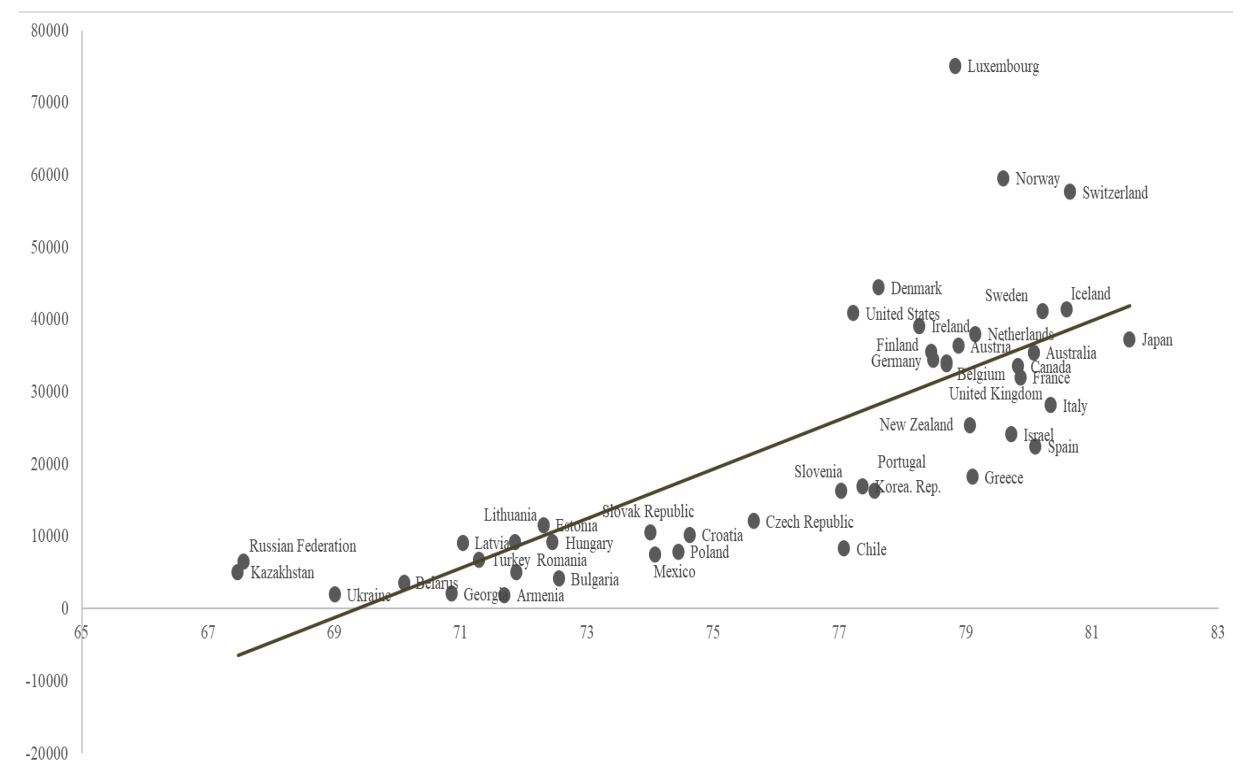

Figure 1. The average GDP per capita (US \$) and total life expectancy at birth (years) in selected countries over the period 1990-2017

Source: authors' own calculation based on The World Bank Open Data (2019).

In the entire sample, Luxembourg was characterized by an enormously high mean GDP per capita that was equal to US $\$ 75,070.34$. The indicator rose significantly from US $\$ 34,645.14$ in 1990 to US $\$ 104,498.74$ in 2017. The life expectancy indicator varied from 75.01 years to 82.69 years, respectively. We did not exclude the data on Luxembourg from the entire sample, but that fact was considered important for subsequent analysis. It should be specifically mentioned that the standard deviation of average life expectancy at birth was equal to 3.96 years, while the standard deviation of mean GDP per capita equaled US $\$ 17,630.46$. Over the investigated period, the total life expectancy at birth in most advanced countries has reached the biological limits. The level of GDP per capita varied significantly. The results of the above analyses should be proved in a further investigation. 
As it was numerically proved, demographic variables have fundamentally affected economic development. Bloom et al. (2007) demonstrated that an increase in population was primarily observed in the non-working-age stratum, affecting both consumption and investment behavior and reducing economic growth. According to Pasichnyi et al. (2017; 2019), in both advanced and emerging markets economies, an increase in the total population had a significantly negative impact on their development. That situation was generally caused by negative shifts in the population's age structure. The influence of the human development index on the resultative variable unexpectedly appeared to be negative as well. That requires further investigations.

Considering the sample and the time scale, the real GDP per capita growth rates were unsustainable and hugely dependent on the mutual interconnections between the economic development determinants. Over the period 1990-2017, all the analyzed variables appeared to be statistically significant (see Table 2, OLS1), while the investigated demographic variables were negative to economic growth. If the average life expectancy increased by $1.00 \%$, the decline in real GDP per capita was equal to $1.23 \%$. It should be specifically mentioned that the life expectancy growth rate was characterized by the lowest volatility. Its standard deviation equaled $0.31 \%$ and showed a slight growth over the period in almost all countries in the sample. The most rapid decline in the analyzed indicator was observed in Iceland in 1995. It was accomplished by a reduction in the real GDP per capita growth rate. The examined indexes were equal to $-1.59 \%$ and $-0.43 \%$, respectively. Meanwhile, over the entire period, the highest life expectancy growth rate was identified in Croatia in 2001. It was associated with rather high economic growth. The investigated variables equaled $2.34 \%$ and $7.51 \%$, respectively. The interconnection between the indicators was uneven and ambiguous due to the complex nature of the life expectancy growth rate, which was simultaneously related to the life quality and the public finances' architectonics.

Considering the periods of 1990-2004 (OLS2) and 2005-2017 (OLS3), the impact of the life expectancy growth rate on economic development was negative and statically significant in both cases. Thus, an increase in the life expectancy growth rate by $1.00 \%$ reduced the real GDP per capita growth rate by $0.36 \%$ and $1.85 \%$, respectively. This difference could be caused by a lack of information on some emerging economies over the period 1990-1995.

Unexpectedly, over the entire period, the working-age population growth rate appeared to be negative to economic growth. Between 1990 and 2004, if the working-age population growth rate increased by $1.00 \%$, the real GDP per capita growth rates fell by $0.94 \%$. However, considering the same time-scale, this variable was statistically insignificant. Between 2005 and 2017, if the working-age population grew by $1.00 \%$, the real GDP per capita growth rate fell by $0.63 \%$. And the interconnection between the variables was statistically significant. As a result, between 1990 and 2017, the interconnection mattered and was negative. If the working-age population increased by $1.00 \%$, the respective reduction in GDP per capita growth rate equaled $0.59 \%$. Over the entire period, the average annual working-age population expansion equaled $0.34 \%$, while 
the standard deviation equaled 0.94\%. Regarding the periods 1990-2004 and 20052017 , the average annual working-age population growth rates equaled $0.48 \%$ and $0.23 \%$, respectively. Summarizing the above, it should be mentioned that an insufficient increase in the working-age stratum accomplished by sustainable life expectancy growth causes population aging.

Table 2. Regressions of economic growth on demographic variables and controls, the sample of 45 countries, 1990-2017, unbalanced panel

\begin{tabular}{|c|c|c|c|}
\hline \multirow{2}{*}{ Variables } & \multicolumn{3}{|c|}{ Period } \\
\hline & OLS1 & OLS2 & OLS3 \\
\hline \multirow{2}{*}{ LifeExp $_{g r}$} & $-1.233^{1}$ & $-0.355^{1}$ & $-1.847^{1}$ \\
\hline & $(0.268)$ & $(0.366)$ & $(0.367)$ \\
\hline \multirow{2}{*}{ WAPop $_{g r}$} & $-0.589^{1}$ & -0.940 & $-0.631^{1}$ \\
\hline & $(0.109)$ & $(0.162)$ & $(0.147)$ \\
\hline \multirow{2}{*}{$R \& D_{\% G D P}$} & $-0.452^{1}$ & $-0.551^{1}$ & -0.226 \\
\hline & $(0.113)$ & $(0.177)$ & $(0.147)$ \\
\hline \multirow{2}{*}{ PubExp $_{\% G D P}$} & $-0.074^{1}$ & $-0.078^{1}$ & $-0.090^{1}$ \\
\hline & $(0.012)$ & $(0.015)$ & $(0.018)$ \\
\hline \multirow{2}{*}{$T l n v_{\% G D P}$} & $0.235^{1}$ & $0.119^{1}$ & $0.289^{1}$ \\
\hline & $(0.023)$ & $(0.035)$ & $(0.030)$ \\
\hline$R^{2}$ & 0.216 & 0.195 & 0.273 \\
\hline$N$ & 1032 & 465 & 567 \\
\hline
\end{tabular}

Notes: The numbers in parentheses are the standard errors of the estimated parameters.

'1' denotes significance at the 1 percent level. $R^{2}$ represents the adjusted coefficient of determination.

Source: the authors' own calculation based on The International Monetary Fund Database (2019),

The World Bank Open Data (2019), The European Commission Database (2019),

and The OECD Data (2019).

Research and development (R\&D) expenditures denote both public and private productive spending, closely associated with an increase in human capital. Thus, the examined interconnection between $\mathrm{R} \& \mathrm{D}$ expenditures and the actual economic development level depended on many determinants. In general, R\&D expenditures are considered to be productive, but their overall effect on the national economy's development level should be examined properly. The composite structure of R\&D expenditures can contradict the main aims of economic development. Theoretically, if the most significant economic advantages were received via direct government grants, the national economy could be deemed paternalistic.

Meanwhile, the empirical data proved that the achieved economic development level was indifferent and slightly negatively interconnected with economic growth. Surprisingly, over the entire period, an increase in the R\&D expenditures-to-GDP ratio by $1.00 \%$ reduced the real GDP growth rates. And, in that case, the average annual decline in the resulting variable was equal to $0.45 \%$. Considering the selected time periods, the dynamic interrelation between the R\&D expenditures-to-GDP ratio and the real GDP per capita growth rate was significant over the period 1990-2004. 
When the empirical base of our study was expanded to include some emerging Eastern and Central European economies, the statistical significance of the investigated interconnection rapidly declined and appeared to be insignificant. Regarding the period 1990-2004, an increase in the R\&D expenditures-to-GDP ratio by $1.00 \%$ was interconnected with a reduction in the GDP per capita growth rate, which was equal to $0.55 \%$. As previously written, over the period 2005-2017, the observed interrelation between the R\&D expenditures-to-GDP ratio and the real economic growth rate appeared to be statistically insignificant. The standard deviation of the investigated human capital-related variable equaled $0.94 \%$. Regarding the different time periods, that specific characteristic grew from $0.81 \%$ to $1.03 \%$.

According to Barro and Sala-i-Martin (2003), the total public expenditures could and should be divided into two separate groups, productive and non-productive, considering their overall impact on production dynamics. Based on the empirical data, the dominance of non-productive public expenditures causes a decline in the real GDP per capita growth rate. The public spending-to-GDP ratio variable was generally negative to economic growth regarding the selected time-scales. Moreover, the negative impact of the investigated independent variable was observed for both advanced and emerging market economies. The variable was hugely dependent on the model of the national economy and the quality of the institutional framework. Due to the extended time period and the quality of the sample, one can see that the public spending-to-GDP ratio varied widely. Its standard deviation changed from $9.89 \%$ to $9.06 \%$.

It should be specifically mentioned that $\mathrm{R} \& \mathrm{D}$ expenditures are hugely dependent on their inherent structure. If the structure was rigid, it could be characterized as an intrinsic aspect of the public spending policy. In emerging economies in the early 1990s, the latter was closely interconnected with the doctrine of paternalistic public finances. Thus, public spending was often determined by the political rather than the economic cycle. The electoral promises - both at the local and national levels - affected the economic performance and quite often deteriorated it.

In general, the total investment indicator - represented by the composite public and private financial efforts - positively affected the growth processes. Over the period 1990-2017, an increase of $1.00 \%$ in the total investment-to-GDP ratio was accomplished by the simultaneous increase in the real GDP per capita growth rate that was equal to $0.24 \%$. The overall effect of investment over the period 1990-2004 (with a respective coefficient that equaled $0.12 \%$ ) was less significant compared with the respective indicator over the period 2005-2017 (with a respective coefficient that equaled $0.29 \%$ ). This proved that the composition of the investment recourses really mattered. Regarding all the analytical periods in the investigated model, the total investment-to-GDP ratio was the only variable that showed a sustainable positive influence on production.

The interrelation between the working-age population stratum and the output growth rate should be investigated properly. The interdependency is shown in Figure 2. 


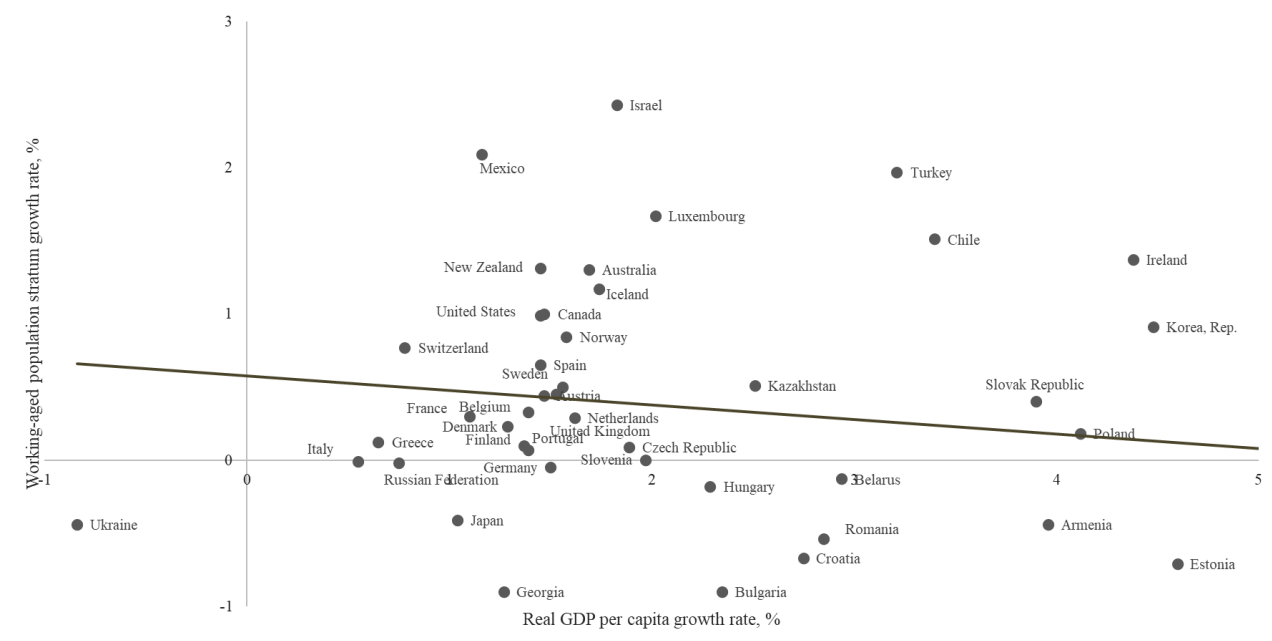

Figure 2. The average working-age population stratum growth rate and the average real GDP per capita growth rate in selected countries over the 1990-2017 period, \%

Source: authors' own calculation based on The World Bank Open Data (2019).

In terms of the real GDP per capita growth rates, over the period 1990-2017, Ukraine maintained a unique position with simultaneous negative average output dynamics and a decline in the economic active population stratum. Some of the investigated advanced countries, namely Germany, Italy, and Japan, were characterized by positive GDP dynamics accomplished by a decrease in the working-age population stratum growth rate. Meanwhile, the influence of the average working-age population stratum growth rate on the output dynamics was ambiguous. There were many emerging market economies (Armenia, Bulgaria, Estonia, Georgia, Hungary, Latvia, Lithuania, Romania, Russian Federation) with a negative working-age population stratum growth rate, while the respective output dynamics was positive. A number of advanced economies were characterized by a positive working-age population stratum growth rate. Poland, Ireland, and South Korea should be mentioned as the countries with the best indicators of population and output dynamics. The working-age population stratum should be considered the most productive, regarding the structure. Future studies should focus on the population's productive capacity.

The legislative framework was essential, as it had an important impact on the agents' behavior and considering macroeconomic efficiency. If the terms of the national legislation were regarded as acceptable for the vast majority of the agents involved, public governance would achieve the best performance. Meanwhile, unfavorable national fiscal legislation fostered migration processes due to the Tiebout hypothesis and decreased the national economy's final results. So, a significant increase in the population's quality of life was closely interconnected with public governance and the respective formal institutional framework. 
An Empirical Study of the Effects of Demographic Factors on Economic Growth...

\section{Discussion}

Based on the empirical data, one can see that over the past three decades, economic development has been hugely dependent on different demographic variables. Meanwhile, the examined social and demographic indicators - the working-age population and the average life expectancy growth rates - had a rather negative impact on the output growth rates. In the case of the adverse interrelation between the working-age population and the real GDP growth rates, a possible explanation can be derived from the quality of the labor force. In our investigation, the working-age stratum of the population was defined according to the International Labour Organisation methodology; however, people aged from 15 to 64 objectively possess incomparable working abilities and competencies. The observed expansions in the above stratum could be caused by increases in the low-skilled and unskilled sub-strata. The latter was described by relatively poor productive capacities and a rather insignificant contribution to public production. Further investigation should cover the structural peculiarities of the working-age stratum.

The overall negative impact of an extended life expectancy can be explained due to the same changes in the population's distribution through the age strata. In advanced and emerging market economies, longevity is directly connected to the tax burden: increased life expectancy induces payments related to social contributions. A very aged population is characterized by significant medical and recreation spending - both public and private - in GDP. Moreover, the dynamics of investment and consumption behavior are hugely dependent on the population's age structure. At the same time, longevity was described as a natural and direct consequence of high economic development.

In this article, the indirect human-capital-related economic growth determinant was represented by the share of R\&D expenditures in GDP. In modern economic discourse, R\&D expenditures are traditionally defined as productive. Nevertheless, in our study, an increase in R\&D spending was associated with a downtrend in public production. The possible explanation was interconnected with the structure of the aforementioned expenditures. In several countries, $R \& D$ expenditures were primarily financed through public funds. If the structure of government spending was infirm, the efficiency of public spending declined significantly. However, the possible solution was closely interconnected with the R\&D activities and private business convergence. If scientific decision-makers were connected to the business programs, their overall effect could be generally high. If the $\mathrm{R} \& \mathrm{D}$ activities were unconnected to the public needs, real GDP would be crucially reduced.

Demographic sustainability should be integrated into the national economic doctrine and determined as society's ability to automatically support and - using implicit compensators - restore its own structure in the context of social stratification. This would refer to a set of significant parameters, including the level of economic activity as well as educational, professional, and competence training. Demographic sustainability optimizes productivity proportions of intellectual and physical capital, provides 
intensification and continuity of production, and increases the welfare of the population. The complex demographic factors, in particular, the working-age population and the average life expectancy growth rates, heavily influence long-term economic growth. Demographic sustainability should be defined as a strategic task for national socio-economic policy. To achieve demographic sustainability, tight coordination of social, fiscal, migration, and cultural policies is required.

\section{Conclusion}

Public production can be described as a complicated multidimensional process that is highly dependent on a set of social, demographic, and economic factors. People influence economic dynamics enormously as they are simultaneously producers and consumers of goods and services. The demographic factors contribute to economic development, and the character of their influence should be investigated properly. We examined the OECD countries (excluding Columbia) and Armenia, Belarus, Bulgaria, Croatia, Georgia, Kazakhstan, Romania, the Russian Federation, and Ukraine over the period 1990-2017. Our initial hypothesis was that demographic factors significantly affected production proportions, determining development vectors. However, the observed demographic variables appeared to be slightly interconnected with the output dynamics, regarding both advanced and developing countries. The possible and predicted demographic dividends and the general character of the demographic transition's impact on the economic development processes in the OECD member-states and selected developing countries were examined. Potential public management measures regarding the highlighted demographic trends were proposed.

Providing comprehensive research, we pointed out some dependencies between the GDP per capita growth rates and the selected demographic variables (the working-age stratum and expected life-span growth rates). We examined states with relatively low, medium, and high development levels. Considering the fact that average life expectancy in the sample was generally dependent on the achieved economic development, some conclusions were reached. In the emerging market countries (e.g., some of the post-Soviet states, as well as Chile, Mexico, and Turkey), the adverse interdependencies between the extended life expectancy and the output dynamics were primarily caused by the quality of the institutional framework. In the advanced countries (the OECD member-states), this interrelation appeared negative, too. However, the possible explanation was that the life-span in those cases had reached biological limits; economic growth in the developed countries was considerably slower than in developing ones. In case of the adverse impact of the working-age stratum on the output dynamics, it was not only the quantity that mattered but the actual quality, as well. Even though the impact of both demographic variables that were studied appeared not to be robust for the entire sample, further research in the aforementioned area with respect to the national economy's peculiarities would be mattered. 
In this investigation, we considered there to be three main groups of impact factors on economic growth. The $1^{\text {st }}$ group was demographic factors that directly related to the quality of human capital. This group included the working-age population and the average life expectancy growth rates. The $2^{\text {nd }}$ group was closely connected to human capital and knowledge management, but indirectly. The investigated variable referred to the R\&D expenditures-to-GDP ratio. The $3^{\text {rd }}$ group was economic controls that primarily related to physical capital: the public spending-to-GDP and total investment-to-GDP ratios. The entire period was divided into two separate periods, i.e., 1990-2004 and 2005-2017.

The total sample was divided into three sub-samples that took into consideration average GDP per capita and mean life expectancy. We found that the above economic and demographic characteristics were directly interconnected: higher life expectancy was observed in the most developed countries. Moreover, that connection appeared to bilateral: significantly high real GDP per capita increased life expectancy. We identified three sub-samples, regarding low, medium, and high average GDP per capita. It was proved that countries with the lowest average life expectancy were simultaneously characterized by relatively low real GDP per capita. High life expectancy was considered the logical and natural consequence of an effective public production structure.

Over the observed periods, the general interdependency - represented by model 3 - appeared to be statistically significant and quite robust, while the impact of the main indicators varied. The vast majority of the investigated variables had a significantly negative impact on the scale of public production. An increase in the life expectancy growth rate by $1.00 \%$ reduced the real GDP per capita growth rate by $1.23 \%$. If the working-age population grew by $1.00 \%$, the output was reduced by $0.59 \%$. Surprisingly, an increase in the R\&D expenditures-to-GDP ratio by $1.00 \%$ slowed down the real GDP per capita growth rate by $0.45 \%$. An increase in the public spending-to-GDP ratio by $1.00 \%$ reduced the output dynamics by $0.07 \%$. The total investment-to-GDP ratio was the only independent variable that had a positive influence on public production: if the ratio increased by $1.00 \%$, the output was increased by $0.24 \%$.

In the numerous previously mentioned scientific investigations, the impact of demographic factors was traditionally included in the global influence of human capital on economic development. In this particular study, we argued that the effect of demographics on economic growth could not be identified with the category of human capital effect. Even though the active economic agents produced GDP, both the production and the consumption mattered. Human capital was commonly associated with production capacity, while demographics determined both the aggregated demand and supply. Thus, in this article, we considered the direct and indirect influence of demographics on developed and emerging market economies. The "overlapping" of the variables was not critical but should be considered in future studies. We augmented the above separation in this paper, taking the transformation experience of Central and Eastern European states into account. 
Regarding the selected time scales, the independent variables had, in general, a similar impact on the output dynamics. Over the period 1990-2004, the impact of the working-age population growth rate on economic development appeared to be statistically insignificant. The same results were obtained when the entire sample was divided into two sub-samples, taking the actual development of the examined economies into account. The empirical investigation proved there is a robust negative interconnection between the observed variables. Meanwhile, the actual impact of demographic variables still needs to be investigated properly.

\section{References}

Acemoglu, D., Johnson, S. (2007), Disease and development: the effect of life expectancy on economic growth, "Journal of Political Economy", 115 (6), pp. 925-985. https:// doi.org/10.1086/529000

Acemoglu, D., Restrepo, P. (2017), Secular stagnation? The effect of aging on economic growth in the age of automation, "American Economic Review", 107 (5), pp. 174-179. https://doi.org/10.1257/aer.p20171101

Ahmad, M., Khan, R.E.A. (2019), Does demographic transition with human capital dynamics matter for economic growth? A Dynamic Panel Data Approach to GMM, "Social Indicators Research", 142 (2), pp. 753-772. https://doi.org/10.1007/s11205 -018-1928-X

Ahsan, H., Haque, M.E. (2017), Threshold effects of human capital: Schooling and economic growth, "Economics Letters”, 156, pp. 48-52. https://doi.org/10.1016/j.econ let.2017.04.014

Barro, R.J., Lee, J.W. (2013), A new data set of educational attainment in the world, 1950-2010, “Journal of Development Economics”, 104, pp. 184-198. https://doi.org /10.1016/j.jdeveco.2012.10.001

Barro, R.J., Sala-i-Martin, X. (2003), Economic growth, $2^{\text {nd }}$ ed., MIT Press, Massachusetts, https://mitpress.mit.edu/books/economic-growth-second-edition (accessed: 21.11.2019).

Bloom, D.E., Canning, D., Sevilla, J. (2001), Economic growth and the demographic transition, NBER Working Paper Series 8685, National Bureau of Economic Research, Cambridge, USA. https://doi.org/10.3386/w8685

Bloom, D.E., Canning, D., Sevilla, J. (2003), The demographic dividend: A new perspective on the economic consequences of population change, Rand Corporation, Santa Monica, Canada. https://www.rand.org/pubs/monograph_reports/MR1274.html

Bloom, D.E., Canning, D., Fink, G., Finlay, J.E. (2007), Does age structure forecast economic growth?, "International Journal of Forecasting", 23 (4), pp. 569-585. https:// doi.org/10.1016/j.ijforecast.2007.07.001

Bloom, D.E., Canning, D., Fink, G., Finlay, J.E. (2009), Fertility, female labor force participation, and the demographic dividend, "Journal of Economic Growth", 14 (2), pp. 79-101. https://doi.org/10.1007/s10887-009-9039-9 
Boucekkine, R., De la Croix, D., Licandro, O. (2002), Vintage human capital, demographic trends, and endogenous growth, "Journal of Economic Theory", 104 (2), pp. 340-375. https://doi.org/10.1006/jeth.2001.2854

Cervellati, M., Sunde, U. (2015), The economic and demographic transition, mortality, and comparative development, "American Economic Journal: Macroeconomics", 7 (3), pp. 189-225. https://doi.org/10.1257/mac.20130170

Cooley, T.F., Henriksen, E., Nusbaum, C. (2019), The Growth-Cost of Demographic Change in Europe, "Review of Economic Dynamics", 1352, pp. 1-30. https://econo micdynamics.org/meetpapers/2019/paper_1352.pdf (accessed: 1.12.2019).

Cuaresma, J.C., Doppelhofer, G., Huber, F., Piribauer, P. (2018), Human capital accumulation and long-term income growth projections for European regions, "Journal of Regional Science”, 58 (1), pp. 81-99. https://doi.org/10.1111/jors.12339

Faggian, A., Partridge, M., Malecki, E.J. (2017), Creating an environment for economic growth: creativity, entrepreneurship or human capital?, "International Journal of Urban and Regional Research”, 41 (6), pp. 997-1009. https://doi.org/10.1111/14 68-2427.12555

Fernihough, A. (2017), Human capital and the quantity-quality trade-off during the demographic transition, "Journal of Economic Growth", 22 (1), pp. 35-65. https:// doi.org/10.1007/s10887-016-9138-3

Galor, O. (2012), The demographic transition: causes and consequences, "Cliometrica", 6 (1), pp. 1-28. https://doi.org/10.1007/s11698-011-0062-7

Hansen, C.W., Lønstrup, L. (2015), The rise in life expectancy and economic growth in the $20^{\text {th }}$ century, “The Economic Journal”, 125 (584), pp. 838-852. https://aca demic.oup.com/ej/article-abstract/125/584/838/5077886? redirectedFrom=fulltext (accessed: 1.12.2019).

Hanushek, E.A. (2016), Will more higher education improve economic growth?, "Oxford Review of Economic Policy”, 32 (4), pp. 538-552. https://doi.org/10.1093/ox rep/grw025

Koziuk, V., Dluhopolskyi, O. (2018), Resource curse: The role of weak institutions and cronysectors, "Ideology and Politics Journal", 1 (9), pp. 68-104.

Kozlovskyi, S., Baidala, V., Tkachuk, O., Kozyrska, T. (2018), Management of the sustainable development of the agrarian sector of the regions of Ukraine, "Montenegrin Journal of Economics”, 14 (4), pp. 175-190. http://dx.doi.org/10.14254/1800-5845 /2018.14-4.12

Kozlovskyi, S., Grynyuk, R., Baidala, V., Burdiak, V., Bakun, Y. (2019), Economic Security Management of Ukraine in Conditions of European Integration, "Montenegrin Journal of Economics", 15 (3), pp. 137-153. http://dx.doi.org/10.14254/1800-58 45/2019.15-3.10

Kozlovskyi, S., Bilenko, D., Kuzheliev, M., Lavrov, R., Kozlovskyi, V., Mazur, H., Taranych, A. (2020), The system dynamic model of the labor migrant policy in economic growth affected by COVID-19, "Global Journal of Environmental Science and Management”, 6, Special Issue (Covid-19), pp. 95-106. http://dx.doi.org/10.22 034/GJESM.2019.06.SI.09

Lee, R.D. (2001), Demographic change and fiscal policy, Cambridge University Press, Cambridge. 
Lee, R.D. (2003), The demographic transition: three centuries of fundamental change, “Journal of Economic Perspectives", 17 (4), pp. 167-190. https://doi.org/10.1257/08 9533003772034943

Lucas Jr., R.E. (2015), Human capital and growth, "American Economic Review", 105 (5), pp. 85-88. https://doi.org/10.1257/aer.p20151065

Malmberg, B. (1994), Age structure effects on economic growth - Swedish evidence, "Scandinavian Economic History Review", 42 (3), pp. 279-295. https:// doi.org/10.1080/03585522.1994.10415889

McGrath, P. (2016), The Relationship between Human Capital and Economic Growth in Ireland. http://dx.doi.org/10.2139/ssrn.2872739

Nagarajan, N.R., Teixeira, A.A. Silva, S.T. (2016), The impact of an ageing population on economic growth: an exploratory review of the main mechanisms, "Análise Social", 218, pp. 4-35. https://www.jstor.org/stable/43755167

Pasichnyi, M. (2017), Empirical study of the fiscal policy impact on economic growth, "Problems and Perspectives in Management", 15 (3), pp. 316-322. http://dx.doi.org /10.21511/ppm.15(3-2).2017.01

Pasichnyi, M., Kaneva, T., Ruban, M., Nepytaliuk, A. (2019), The impact of fiscal decentralization on economic development, "Investment Management and Financial Innovations”, 16 (3), pp. 29-39. http://dx.doi.org/10.21511/imfi.16(3).2019.04

Pelinescu, E. (2015), The impact of human capital on economic growth, "Procedia Economics and Finance”, 22, pp. 184-190. https://doi.org/10.1016/S2212-5671(15)00258-0

Romer, P.M. (1990), Endogenous technological change, "Journal of Political Economy", 98 (5, Part 2), pp. S71-S102. https://doi.org/10.1086/261725

Sanchez-Romero, M., Lee, R.D., Prskawetz, A. (2018), Redistributive effects of different pension structures when longevity varies by socioeconomic status in a general equilibrium setting. Population Association of America, Manuscript, pp. 1-56. https:// www.econstor.eu/handle/10419/203628 (accessed: 1.12.2019).

Teixeira, A.A., Queirós, A.S. (2016), Economic growth, human capital and structural change: A dynamic panel data analysis, "Research Policy", 45 (8), pp. 1636-1648. https://doi.org/10.1016/j.respol.2016.04.006

The European Commission Database (2019), https://ec.europa.eu/eurostat/data/data base (accessed: 21.11.2019).

The International Monetary Fund Database (2019), https:/www.imf.org/en/Data (accessed: 21.11.2019).

The OECD Data (2019), https://stats.oecd.org/ (accessed: 21.11.2019).

The World Bank Open Data (2019), https://data.worldbank.org/ (accessed: 21.11.2019).

Uddin, G.A., Alam, K., Gow, J. (2016), Population age structure and savings rate impacts on economic growth: Evidence from Australia, "Economic Analysis and Policy", 52, pp. 23-33. https://doi.org/10.1016/j.eap.2016.08.002 


\section{Streszczenie}

\section{Badanie empiryczne wpływu czynników demograficznych na wzrost gospodarczy w krajach rozwiniętych i rozwijających się}

W artykule zaproponowano zaktualizowane podejście do badania wpływu czynników demograficznych na wzrost gospodarczy. Wstępna hipoteza zakładała, że czynniki te w istotny sposób wpływają na proporcje produkcji, determinując kierunki rozwoju. Ramy instytucjonalne uwzględniały przewidywalne zmiany dynamiki produkcji. W artykule zbadano, wykorzystując niezbilansowane dane panelowe, istotne statystycznie związki między zmiennymi demograficznymi a wzrostem gospodarczym dla krajów OECD (z wyłączeniem Kolumbii) oraz Armenii, Białorusi, Bułgarii, Chorwacji, Gruzji, Kazachstanu, Rumunii, Federacji Rosyjskiej i Ukrainy w latach 1990-2017. Badanie miało na celu podkreślenie związku między kształtowaniem się zmiennych demograficznych (np. tempa wzrostu populacji w wieku produkcyjnym i tempa wzrostu średniej długości życia) a wzrostem gospodarczym. Badanie było próbą odpowiedzi na pytanie czy wpływ czynników demograficznych na gospodarkę był taki sam dla badanych krajów rozwiniętych i rozwijających się. W omawianym okresie znaczny wzrost oczekiwanej długości życia niekorzystnie wpłynął na dynamikę realnego PKB per capita. Badanie empiryczne wykazało, że oczekiwana długość życia jest silnie powiązana z nominalnym PKB per capita. W krajach rozwiniętych ten wskaźnik demograficzny był znacznie wyższy niż na rynkach wschodzących. Okazało się, że wzrost liczby ludności w wieku produkcyjnym radykalnie zmniejszył również dynamikę produkcji, ale związek ten nie był silny. Aby uzyskać pozytywne efekty zarządzania publicznego w perspektywie długoterminowej, należy uwzględnić ramy instytucjonalne. Główne zmienne demograficzne powinny być odpowiednio prognozowane i skalibrowane pod kątem potencjalnych endogenicznych czynników ekonomicznych. Dla osiąganych wskaźników wzrostu gospodarczego ważne są zarówno inwestycje publiczne, jak i prywatne. Autorzy sugerują wyważone podejście do polityki makroekonomicznej w zakresie uwarunkowań zarówno demograficznych, jak i instytucjonalnych.

Słowa kluczowe: ludność, kapitał ludzki, równowaga demograficzna, ramy instytucjonalne, wzrost gospodarczy 